\title{
Mandibular Measurements and Discrete Nonmetric Traits Compared in Distance Studies of Six Non-tribal Indian Skeletal Samples
}

\author{
R. K. PATHAK ${ }^{1,2)}$ and S. KAUL ${ }^{1)}$ \\ 1) Department of Anthropology, Panjab University \\ 2) Pool Officer (C.S.I.R.)
}

\begin{abstract}
Seven metric and six nonmetric traits have been used to describe and discriminate mandibular characteristics of six non-tribal populations of India. Analyses of the six samples indicate that while metric traits possess a slightly better discriminating power than nonmetric traits in differentiating populations in the present investigation, both kinds of traits reveal a similar pattern of interpopulation differences. It is felt that both metric and nonmetric traits should be utilized, whenever possible, to derive maximum information in population studies.
\end{abstract}

Keywords Mandible, Metric-nonmetric traits, India

\section{Introduction}

The use of minor skeletal variants to differentiate between human populations, archaeological or extant, has assumed importance in the past few years. A survey of literature reveals that studies on nonmetric traits have exclusively been conducted on European, American, Australian or Japanese populations (BERRY and BERRY, 1967; ARdito, 1977; CorruCCINI, 1974; FinNeGan, 1972; OsSENBERG, 1976 ; KeLlock and PARSONS, 1970a and b; DoDO, 1974; Mouri, 1976; RoTHHAMmer et al., 1984). Previous researches in this area involving skeletal material of Indian populations have been mostly descriptive, limited in most cases to the recording of usually single morphological traits (KAUL et al., 1979a). KAUL et al. (1979b) studied discrete cranial variation in four Indian populations (three living and one extinct) and measured the degree of divergence between them.

The relative worth of metric and nonmetric skeletal variants as biological indicators in population studies has also been discussed recently. Several workers, including BERRY and BERRY (1967, 1972), OSSENBERG (1970) and Pietrusewsky (1971) assert the superiority of nonmetric variants over metrical ones for ascertaining biological distances between populations. Others, like JANTZ (1970), HowELlS (1970, 1972) and RightMiRe (1972) are critical of the worth

Article No. 8615 Received June 30, 1986. 
of nonmetrical variants and defend the traditional metrical methods in population studies.

Apart from documenting the extent and nature of variation among six non-tribal population samples from India on the basis of metric and nonmetric morphological traits of the mandible, the present study attempts to evaluate the anthropological significance of nonmetric in comparison to metric skeletal variation.

\section{Material and Methods}

The present study is based on the 668 adult mandibles of six different non-tribal population samples from India. This material examined in various medical schools (colleges) and other institutions in the country, is distributed according to the State of origin as follows: Uttar Pradesh (UP)-186 ; Andhra Pradesh (AP)-121; Madhya Pradesh (MP)125 ; Karnataka (Ka)-105; Maharashtra (Ma)106 ; and, Bihar (Bi)-25.

Cremation of the dead is a common ritual among the people of India. This makes it difficult to obtain human skeletal material for research purposes. However, osteological museums and laboratories in various medical institutions (schools) and anthropology departments in some universities in the country have their own collections of human skeletal material. This material is obtained either from excavations done at archaeological sites or from unclaimed cadavers, and in many cases collected from river banks (KAUL and PATHAK, 1984).

Human skeletal parts collected from river banks are mostly of people of low socioeconomic status. These people cannot afford the cost of cremation. Therefore, instead of being cremated the body is usually weighed with a heavy load and submerged in the nearest river. Soft parts of the body either disintegrate or are eaten away by aquatic animals. The hard bony parts of the body wash ashore where they may be collected. The source, ethnic background, and other details of the material are given elsewhere (PATHAK, 1983). In the absence of authentic background information and with the poor state of preservation of the material, determination of sex of the mandibles (and skulls) was difficult.

The following seven measurements and six nonmetric traits were used in the present study :

Metric Traits: (1) Gonion-menton length, (2) Bicondylar breadth, (3) Bigonial breadth, (4) Ramus height, (5) Ramus breadth, (6) Corpus thickness, and (7) Symphyseal height.

Nonmetric Traits: (1) Mandibular torus, (2) Genial tubercles, (3) Accessory mental foramen, (4) Mylohyoid bridge, (5) Accessory mylohyoid foramen, and (6) Gonial eversions.

Measurements were taken according to Trevor (1957) and MARTIN and SALlER (1957). The definitions and present-absent criteria for nonmetric traits follow CoRRUCCINI (1974). Whereas measurements were taken on the left side of the mandible only, both sides were considered for recording the nonmetric traits, thus giving a sample size equal to $2 \mathrm{~N}$ for the latter.

Inter-population differences were calculated by applying 'student's $t$-test' and ' $\chi^{2}$-test' to metric and nonmetric data, respectively. SOKAL and RoHLF's (1969) method of 'combining probabilities from tests of significance' was used for a comparison of the two groups of traits.

\section{Results}

Metric Traits

The mean, standard deviation and coefficient of variation for mandibular measure- 
Table 1. Mean, standard deviation and coefficient of variation for mandibular measurements in six Indian populations.

\begin{tabular}{|c|c|c|c|c|c|}
\hline Measurement $\mathrm{F}$ & Population & $\mathrm{N}$ & $\begin{array}{l}\text { Mean } \\
(\mathrm{cm})\end{array}$ & $\mathrm{SD}$ & $\mathrm{CV}$ \\
\hline \multirow{6}{*}{$\begin{array}{l}\text { Gonion-menton } \\
\text { length }\end{array}$} & UP & 186 & 7.40 & .41 & 5.52 \\
\hline & $\mathrm{AP}$ & 121 & 7.30 & .43 & 5.90 \\
\hline & MP & 125 & 7.36 & .41 & 5.64 \\
\hline & $\mathrm{Ka}$ & 105 & 7.14 & .45 & 6.35 \\
\hline & $\mathrm{Ma}$ & 106 & 7.31 & .45 & 6.17 \\
\hline & $\mathrm{Bi}$ & 25 & 7.56 & .48 & 6.30 \\
\hline \multirow{6}{*}{$\begin{array}{c}\text { Bicondylar } \\
\text { breadth }\end{array}$} & UP & 186 & 11.15 & .59 & 5.33 \\
\hline & $\mathrm{AP}$ & 121 & 10.87 & .64 & 5.92 \\
\hline & MP & 123 & 11.08 & .59 & 5.35 \\
\hline & $\mathrm{Ka}$ & 105 & 11.07 & .63 & 5.66 \\
\hline & $\mathrm{Ma}$ & 104 & 11.05 & .59 & 5.34 \\
\hline & $\mathrm{Bi}$ & 25 & 11.02 & .73 & 6.63 \\
\hline \multirow{6}{*}{$\begin{array}{l}\text { Bigonial } \\
\text { breadth }\end{array}$} & UP & 186 & 8.64 & .65 & 7.55 \\
\hline & $\mathrm{AP}$ & 121 & 8.46 & .56 & 6.57 \\
\hline & MP & 125 & 8.66 & .52 & 6.06 \\
\hline & $\mathrm{Ka}$ & 105 & 8.54 & .61 & 7.17 \\
\hline & $\mathrm{Ma}$ & 106 & 8.69 & .63 & 7.29 \\
\hline & $\mathrm{Bi}$ & 25 & 8.60 & .58 & 6.77 \\
\hline \multirow[t]{6}{*}{ Ramus height } & UP & 186 & 5.64 & .59 & 10.50 \\
\hline & $\mathrm{AP}$ & 121 & 5.52 & .60 & 10.83 \\
\hline & MP & 125 & 5.81 & .52 & 9.03 \\
\hline & $\mathrm{Ka}$ & 105 & 5.50 & .58 & 10.55 \\
\hline & $\mathrm{Ma}$ & 106 & 5.58 & .68 & 12. 26 \\
\hline & $\mathrm{Bi}$ & 25 & 5.47 & .53 & 9.73 \\
\hline \multirow[t]{6}{*}{ Ramus breadth } & h UP & 186 & 3.09 & .27 & 8. 69 \\
\hline & $\mathrm{AP}$ & 121 & 3.01 & .32 & 10.71 \\
\hline & MP & 125 & 3.06 & .28 & 9.27 \\
\hline & $\mathrm{Ka}$ & 105 & 3.00 & .32 & 10.76 \\
\hline & $\mathrm{Ma}$ & 106 & 2.99 & .33 & 10.91 \\
\hline & $\mathrm{Bi}$ & 25 & 3.21 & .31 & 9.56 \\
\hline \multirow{6}{*}{$\begin{array}{l}\text { Corpus } \\
\text { thickness }\end{array}$} & UP & 186 & 1.07 & .15 & 14.49 \\
\hline & $\mathrm{AP}$ & 121 & 1.08 & .15 & 13. 67 \\
\hline & MP & 125 & 1.01 & .16 & 16. 32 \\
\hline & $\mathrm{Ka}$ & 105 & 0.98 & .14 & 14.59 \\
\hline & $\mathrm{Ma}$ & 106 & 1.01 & .15 & 14.75 \\
\hline & $\mathrm{Bi}$ & 25 & 1.08 & .14 & 12.82 \\
\hline \multirow{6}{*}{$\begin{array}{l}\text { Symphyseal } \\
\text { height }\end{array}$} & UP & 186 & 2.52 & .38 & 15. 17 \\
\hline & AP & 121 & 2.45 & .41 & 16.76 \\
\hline & MP & 125 & 2.86 & .37 & 12.98 \\
\hline & $\mathrm{Ka}$ & 105 & 2.62 & .43 & 16.29 \\
\hline & $\mathrm{Ma}$ & 106 & 2.60 & .37 & 14.14 \\
\hline & $\mathrm{Bi}$ & 25 & 2.51 & .39 & 15.52 \\
\hline
\end{tabular}

ments in the six Indian populations are given in Table 1 , and the $t$-values between different population combinations for each measurement presented in Table 2 . No consistent pattern of differences between the seven mandibular metric traits of the six population groups is revealed. However, corpus thickness and symphyseal height show maximum inter-population variation, followed by gonion-menton length, ramus breadth and ramus height. Bicondylar and bigonial breadths discriminate only a few population pairs.

Nonmetric Traits

The frequency of incidence of nonmetric traits for the six samples is given in Table 3. Mandibular torus has the lowest and genial tubercles the highest frequency in all the populatons. Table 4 lists the $\chi^{2}$-values between pairs of populations for each of the six nonmetric traits. No consistent pattern of inter-population differences are seen. However, genial tubercles, followed by mylohyoid bridge and gonial eversions emerge as the most discriminating traits between the populations, whereas accessory mylohyoid foramen turns out to be the least discriminating trait in the mandible.

\section{Metric vs Nonmetric Traits}

Out of a total of $105 t$-values for metrical traits (Table 2) 44.76 per cent values are significant, while out of $90 \chi^{2}$-values for nonmetric traits (Table 4) only 30 per cent values are statistically significant. This seems to show that, in comparison to nonmetric traits, metric traits are better indicators of differences between the populations considered in the present study.

In Table 5 are presented the differences between group values of metric and nonmetric characters based on probablities from the two tests of significance applied earlier. 
Table 2. Population differences ( $t$-values) for each mandibular measurement.

\begin{tabular}{|c|c|c|c|c|c|c|c|}
\hline $\begin{array}{l}\text { Traits/ } \\
\text { Populations }\end{array}$ & $\begin{array}{l}\text { Gonion } \\
\text { menton } \\
\text { length }\end{array}$ & $\begin{array}{l}\text { Bicondylar } \\
\text { breadth }\end{array}$ & $\begin{array}{l}\text { Bigonial } \\
\text { breadth }\end{array}$ & $\begin{array}{l}\text { Ramus } \\
\text { height }\end{array}$ & $\begin{array}{l}\text { Ramus } \\
\text { breadth }\end{array}$ & $\begin{array}{l}\text { Corpus } \\
\text { thickness }\end{array}$ & $\begin{array}{l}\text { Symphyseal } \\
\text { height }\end{array}$ \\
\hline UP-AP & $2.027^{*}$ & $-3.811^{* * *}$ & $2.548^{*}$ & -1.763 & $2.446^{*}$ & -0.777 & 1. 403 \\
\hline UP-MP & 0.782 & 0.929 & -0.237 & $-2.640^{* *}$ & 0.912 & $3.293^{* * *}$ & $-7.859^{* * *}$ \\
\hline UP-Ka & $5.016^{* * *}$ & 1.034 & 1.305 & $1.970^{*}$ & $2.720 * *$ & $4.638^{* * *}$ & $-2.202^{*}$ \\
\hline UP-Ma & 1.613 & 1.317 & -0.632 & 0.813 & $2.804^{* *}$ & 3. $189 * * *$ & -1.809 \\
\hline UP-Bi & -1.821 & 0.944 & 0.325 & 1.367 & $-2.023^{*}$ & 0.393 & 0.026 \\
\hline AP-MP & -1.143 & $-2.643^{* *}$ & $-2.902 * *$ & $-4.119 * * *$ & -1.398 & 3. $720^{* * *}$ & $-8.169 * * *$ \\
\hline $\mathrm{AP}-\mathrm{Ka}$ & $2.743^{* *}$ & $-2.321^{*}$ & -1.051 & 0.241 & 0.300 & $5.098^{* * *}$ & $-3.074^{* *}$ \\
\hline $\mathrm{AP}-\mathrm{Ma}$ & -0.265 & $-2.147^{*}$ & $-2.954^{* *}$ & -0.709 & 0.375 & $3.701^{* * *}$ & $-2.831^{* *}$ \\
\hline $\mathrm{AP}-\mathrm{Bi}$ & $-2.702^{* *}$ & -1.039 & -1.128 & 0.373 & $-2.859 * *$ & 0.331 & -0.696 \\
\hline $\mathrm{MP}-\mathrm{Ka}$ & $3.893^{* * *}$ & -0.154 & 1.577 & $4.308^{* * *}$ & 1.675 & 1.213 & 4. $479 * * *$ \\
\hline MP-Ma & 0.808 & 0.399 & -0.435 & $2.951^{* *}$ & 1.750 & -0.059 & $5.332^{* * *}$ \\
\hline $\mathrm{MP}-\mathrm{Bi}$ & $-2.133^{*}$ & 0.435 & 0.522 & $2.979 * *$ & $-2.329 *$ & $-2.083^{*}$ & 4. $210^{* * *}$ \\
\hline $\mathrm{Ka}-\mathrm{Ma}$ & $-2.841^{* *}$ & 0.226 & -1.765 & -0.908 & 0.073 & -1.299 & 0.442 \\
\hline $\mathrm{Ka}-\mathrm{Bi}$ & $-4.141^{* * *}$ & 0.322 & -0.423 & 0.229 & $-3.006^{* *}$ & $-3.095^{* *}$ & 1. 168 \\
\hline $\mathrm{Ma}-\mathrm{Bi}$ & $-2.416^{*}$ & 0.199 & 0.679 & 0.741 & $-3.023^{* *}$ & $-2.205^{*}$ & 1.029 \\
\hline
\end{tabular}

$* \mathrm{p}<.05 \quad * * \mathrm{p}<.01 \quad * * * \mathrm{p}<.001$

Table 3. Incidence of nonmetric traits in mandibles of six Indian populations.

\begin{tabular}{|c|c|c|c|c|c|c|}
\hline \multirow{2}{*}{ Traits } & UP & AP & MP & $\mathrm{Ka}$ & Ma & $\mathrm{Bi}$ \\
\hline & $\mathrm{N}=372$ & $\mathrm{~N}=242$ & $N=250$ & $N=218$ & $\mathrm{~N}=212$ & $\mathrm{~N}=46$ \\
\hline Mandibular torus & 27 & 18 & 5 & 9 & 10 & 0 \\
\hline Genial tubercles & 274 & 173 & 141 & 143 & 136 & 40 \\
\hline Accessory mental foramen & 78 & 24 & 37 & 40 & 34 & 6 \\
\hline Mylohyoid bridge & 38 & 58 & 34 & 38 & 38 & 6 \\
\hline Accessory mylohyoid foramen & 129 & 79 & 98 & 91 & 78 & 14 \\
\hline Gonial eversions & 202 & 126 & 90 & 94 & 106 & 22 \\
\hline
\end{tabular}

All the fifteen comparisons of metric traits are statistically significant, whereas only nine out of fifteen comparisons for nonmetric traits are significant. The last column in Table 5 gives the differences in $\chi^{2}$-values between the two trait categories. Though only two $t$-values are statistically significant, metric traits seem to exhibit a clear preference over the nonmetric traits.

\section{Discussion}

There is a continuing debate on the validity of employing nonmetric discrete skeletal traits instead of metric variables and vice versa. A number of authors have focussed their attention on this issue but the final resolution appears elusive. RightMIRE (1972), GAHERTy (1974), CORRUCCINI (1974) and 
Table 4. Population differences ( $\chi^{2}$-values) for each mandibular trait.

\begin{tabular}{|c|c|c|c|c|c|c|}
\hline $\begin{array}{l}\text { Traits/ } \\
\text { Populations }\end{array}$ & $\begin{array}{l}\text { Mandibular } \\
\text { torus }\end{array}$ & $\begin{array}{l}\text { Genial } \\
\text { tubercles }\end{array}$ & $\begin{array}{l}\text { Accessory } \\
\text { mental } \\
\text { foramen }\end{array}$ & $\begin{array}{l}\text { Mylohyoid } \\
\text { bridge }\end{array}$ & $\begin{array}{l}\text { Accessory } \\
\text { mylohyoid } \\
\text { foramen }\end{array}$ & $\begin{array}{l}\text { Gonial } \\
\text { eversions }\end{array}$ \\
\hline UP-AP & 0.01 & 0.35 & $12.92^{* * *}$ & $21.02^{* * *}$ & 0.27 & 0.29 \\
\hline UP-MP & $8.47^{* *}$ & $20.05^{* * *}$ & 3.77 & $16.74^{* * *}$ & 1.32 & $20.11^{* * *}$ \\
\hline $\mathrm{UP}-\mathrm{Ka}$ & 2.35 & $4.31^{*}$ & 0.59 & $6.73^{* *}$ & 2.98 & $6.87^{* *}$ \\
\hline UP-Ma & 1.47 & $5.83^{*}$ & 2.12 & $7.48^{* *}$ & 0.26 & 1.00 \\
\hline $\mathrm{UP}-\mathrm{Bi}$ & 1.86 & $3.87^{*}$ & 1.60 & 0.35 & 0.33 & 0.69 \\
\hline AP-MP & $8.16^{* *}$ & $12.12^{* * *}$ & 2.70 & $8.69 * *$ & 2.29 & $12.89^{* * *}$ \\
\hline $\mathrm{AP}-\mathrm{Ka}$ & 2.27 & 1.85 & $6.81^{* *}$ & 2.97 & $4.07^{*}$ & 3.68 \\
\hline AP-Ma & 1.45 & 2.80 & 3.80 & 2.47 & 0.86 & 0.35 \\
\hline $\mathrm{AP}-\mathrm{Bi}$ & 1.74 & $4.80^{*}$ & 0.40 & 2.67 & 0.09 & 0.28 \\
\hline $\mathrm{MP}-\mathrm{Ka}$ & 1.82 & $4.13^{*}$ & 1.07 & 1.32 & 0.31 & 2.47 \\
\hline MP-Ma & 2.70 & 2.87 & 0.14 & 1.63 & 0.29 & $9.21^{* *}$ \\
\hline $\mathrm{MP}-\mathrm{Bi}$ & 0.01 & $15.27^{* * *}$ & 0.10 & 0.01 & 1. 27 & 2.31 \\
\hline $\mathrm{Ka}-\mathrm{Ma}$ & 0.09 & 0.10 & 0.40 & 0.02 & 1.10 & 2.05 \\
\hline $\mathrm{Ka}-\mathrm{Bi}$ & 0.40 & $8.15^{* *}$ & 0.74 & 0.53 & 2.03 & 0.34 \\
\hline $\mathrm{Ma}-\mathrm{Bi}$ & 0.60 & $9.07 * *$ & 0.26 & 0.64 & 0.67 & 0.07 \\
\hline
\end{tabular}

Table 5. Statistical parameters of significance differences between populations for metric and nonmetric traits.

\begin{tabular}{|c|c|c|c|c|c|c|c|c|c|c|c|}
\hline \multirow{2}{*}{$\begin{array}{l}\text { Traits/ } \\
\text { Populations }\end{array}$} & \multicolumn{3}{|c|}{ Metric } & \multicolumn{3}{|c|}{ Nonmetric } & \multicolumn{5}{|c|}{ Metric vs. Nonmetric } \\
\hline & $\chi^{2}$ & d. f. & $\mathrm{p}$ & $\chi^{2}$ & d. f. & $\mathrm{p}$ & \multicolumn{3}{|c|}{ Weighed $\chi^{2}$-values* } & F-value & $\mathrm{p}$ \\
\hline $\mathrm{UP}-\mathrm{AP}$ & 60.880 & 14 & .001 & 35.496 & 12 & .001 & 4. 349 & vs. & 2.958 & 1.47 & .50 \\
\hline UP-MP & 55.019 & 14 & .001 & 74.944 & 12 & .001 & 3.930 & vs. & 6.245 & 0.63 & - \\
\hline UP-Ka & 72.924 & 14 & .001 & 35.691 & 12 & .001 & 5.209 & vs. & 2.974 & 1.75 & .25 \\
\hline UP-Ma & 48.547 & 14 & .001 & 28.300 & 12 & .01 & 3.468 & vs. & 2. 358 & 1.47 & .50 \\
\hline UP-Bi & 28.328 & 14 & .02 & 16.795 & 12 & .20 & 2.023 & vs. & 1.400 & 1.45 & .50 \\
\hline AP-MP & 83.283 & 14 & .001 & 59.769 & 12 & .001 & 5.949 & vs. & 4.981 & 1.19 & .50 \\
\hline $\mathrm{AP}-\mathrm{Ka}$ & 60.632 & 14 & .001 & 33.651 & 12 & .001 & 4. 331 & vs. & 2.804 & 1.54 & .25 \\
\hline $\mathrm{AP}-\mathrm{Ma}$ & 53.742 & 14 & .001 & 21.210 & 12 & .05 & 3.839 & vs. & 1.768 & 2.17 & .10 \\
\hline $\mathrm{AP}-\mathrm{Bi}$ & 38.249 & 14 & .001 & 17.691 & 12 & .20 & 2.732 & vs. & 1.474 & 1.85 & .25 \\
\hline $\mathrm{MP}-\mathrm{Ka}$ & 73.114 & 14 & .001 & 20.330 & 12 & .10 & 5.222 & vs. & 1.694 & 3.08 & .05 \\
\hline MP-Ma & 46.282 & 14 & .001 & 25.970 & 12 & .02 & 3.306 & vs. & 2. 164 & 1.53 & .25 \\
\hline MP-Bi & 60.742 & 14 & .001 & 25.762 & 12 & .02 & 4.339 & vs. & 2.147 & 2.02 & .25 \\
\hline $\mathrm{Ka}-\mathrm{Ma}$ & 32.499 & 14 & .01 & 9.153 & 12 & .70 & 2.321 & vs. & 0.763 & 3.04 & .05 \\
\hline $\mathrm{Ka}-\mathrm{Bi}$ & 56.212 & 14 & .001 & 20.119 & 12 & .10 & 4.015 & vs. & 1.677 & 2.39 & .10 \\
\hline $\mathrm{Ma}-\mathrm{Bi}$ & 43.236 & 14 & .001 & 17.996 & 12 & .20 & 3.088 & vs. & 1.500 & 2.06 & .25 \\
\hline
\end{tabular}

* $\chi^{2}$ values divided by d.f. 
CARPEnTER (1976), among others, have approached this problem by using the congruence of patterns of metrical and nonmetrial cranial variation with geography and culture as a criterion. ROTHHAMMER et al. (1984) compared the chronologic nonmetrical cranial character variation with metrical variables among the prehistoric Andean populations in order to study the microevolutionary dynamics of basically uncorrelated sets of biological characters. Although only a few correlations, derived from a pooled variance-covariance matrix of 23 craniometrical and nonmetrical traits, were significant the authors (ROTHHAMMER et al.) consider both sets of traits essentially independent exhibiting congruent patterns of chronologic variation. Furthermore, they note that the rate of change with time of both metric and nonmetric variables is relatively constant and notably similar. While examining the anatomical association between metrical and nonmetrical traits, CORRUCCINI (1976) concluded that "a low but observable general influence" is exerted by one set of characters upon the other.

ROSENBERG et al. (1983) used fifteen metric traits and seven discrete traits to describe and discriminate the biological characteristics of the mandible of three indigenous populations in Israel and Sinai. Analyses of the three samples revealed small differences between metric and nonmetric traits. However, no significant statistical advantages of one over the other were found. This was interpreted to indicate that metric and nonmetric traits were affected by the genetic process of isolation and by environmental factors to a similar degree.

In the present study, analyses of six nontribal samples reveal that while metric traits exhibit a slightly better discriminating power than nonmetric traits in differentiating various populations, both sets of traits show a similar pattern of differences between various population combinations considered. This receives corroboration from the fact that the metric $\chi^{2}$ and nonmetric $\chi^{2}$ values (Table 5) bear a significant association with each other $(\mathrm{r}=0.54, \mathrm{p}<0.05 ; \mathrm{df}=13)$. This can be interpreted to show that the two kinds of skeletal variants are not completely independent. In the opinion of CHEvERUD et al. (1979), both kinds share a moderate to high degree of developmental determination and there is no biological reason to favour either kind of trait for use in population studies. While statistically metric traits may be more tractable, and in matters of fragmented and small sample, nonmetric traits may be preferable, the authors feel that whenever possible both kinds of traits (i. e., metric and nonmetric) should be utilized simultaneously to derive maximum information in population studies.

\section{Acknowledgements}

The senior author would like to acknowledge the financial support of the Council of Scientific \& Industrial Research, New Delhi in the preparation of the manuscript.

\section{抄録}

下顎骨の計測值と非計測的形質による

インド人 6 集団間の差の此較

R. K. PathaK, S. Kaul

インド人 6 集団の下顎骨について 7 項目の計测と 6 項目の非計測的形質の出現率調查をおこない，集団間 の差を検定した結果, 計測値の方が非計測的形質に比 して差の検出力にややすぐれていることが明らかにな ったが，集団間の差のパタンには著しい差は認められ 
なかった。集団研究において最大の情報を引き出すた めには, 可能なかぎり, 計测と非計测的形質の両者を 活用すべきであると考えられる.

\section{（抄録：山口 敏）}

\section{References}

ARDito, G., 1977: The epigenetic variations of the skulls in some ancient and recent Italian population. J. Hum. Evol., 6 : 689-695.

Berry, A.C. and R. J. Berry, 1967 : Epigenetic variation in the human cranium. J. Anat., $101: 361-379$.

Berry, A. C. and R. J. BERry, 1972: Epigenetic polymorphism in primate skeleton. In: "Comparative Genetics in Monkeys, Apes and Man" (A.B. Chiarelli, ed.), Academic Press, New York.

Carpenter, J.C., 1976: A comparative study of metric and nonmetric traits in a series of modern crania. Am. J. Phys. Anthrop., 45 : 337-344.

Cheverud, J.M., J.E. Buikstra and E. TwiCHELL, 1979: Relationships between nonmetric skeletal traits and cranial size and shape. Am. J. Phys. Anthrop., 50 : 191-198.

Corruccini, R.S., 1974: An examination of the meaning of cranial discrete traits for human skeletal biological studies. Am. J. Phys. Anthrop., $40: 425-446$.

CORRUCCINI, R. S., 1976: The interaction between nonmetric and metric cranial variation. Am. J. Phys. Anthrop., 44 : 285-294.

Dodo, Y., 1974: Non-metrical cranial traits in the Hokkaido Ainu and the Northern Japanese of recent times. J. Anthrop. Soc. Nippon, 82 : $31-51$.

Finnegan, M. J., 1972 : "Population Definition on the Northwest Coast by Analysis of Discrete Character Variation", Ph. D. Dissertation, University of Colorado.

Gaherty, G., 1974: Discrete traits, cranial measurements, and non-biological data in Africa. Am. J. Phys. Anthrop., $40: 136$.

Howells, W. W., 1970 : Theory and methodology : multivariate analysis of human crania. Proc. VIIIth Int. Cong. Anthrop. Ethnol. Sci., 1: 1-3. Howells, W. W., 1972: Analysis of patterns of variation in crania of recent man. In: "The Functional and Evolutionary Biology of Primate". (R. Tuttle, ed.), Aldine-Atherton, Chicago.
JANTZ, R. L., 1970: "Change and variation in skeletal populations of Arikara Indians", Thesis, University of Kansas.

KAUl, S., V. ANAND and S. R. K. Chopra, 1979a : Discrete nonmetric variants of the human skull - a review of their aetiology and their incidence in Indian populations. Ind. J. Phys. Anthrop. Hum. Genet., 5 : 137-161.

Kaul, S., V. ANAND and R. S. Corruccini, 1979b : Nonmetric variation of the skull in samples of four Indian populations. J. Hum. Evol., 8 : 693697.

Kaul, S. and R.K. Pathak, 1984: The mylohyoid bridge in four population samples from India, with observations on its suitability as a genetic marker. Am. J. Phys. Anthrop., 65: 213-218.

Kellock, W.L. and P.A. PARsons, 1970a : Variation of minor nonmetrical cranial variants in Australian aborigmes. Am. J. Phys. Anthrop., $32: 409-422$.

Kellock, W.L. and P.A. Parsons, 1970b: A comparison of the incidence of minor nonmetrical cranial variants in Australian aborigines with those of Melanesia and Polynesia. Am. J. Phys. Anthrop., 33 : 235-240.

Martin, R. and K. Saller, 1957: "Lehrbuch der Anthropologie". Gustav Fischer Verlag, Stuttgart.

Mouri, T., 1976: A study of nonmetrical cranial variants of the modern Japanese in the Kinki District. J. Anthrop. Soc. Nippon, 84 : 191-203.

OssenberG, N.S., 1970: The influence of artificial cranial deformation on discontinuous traits. Am. J. Phys. Anthrop., $33: 357-372$.

OssenberG, N. S., 1976: Within and between race distances in population studies based on discrete traits of the human skull. Am. J. Phys. Anthrop., 45 : 701-716.

PATHAK, R.K., 1983: "Discrete nonmetric and metric morphological variations of the human skull : a study based on six skeletal population samples of India". Unpublished Ph. D. Thesis, Panjab University, Chandigarh.

Pietrusewsky, M., 1971: Application of distance statistics to anthroposcopic data and a comparison of results with those obtained by using discrete traits of the skull. Arch. Phys. Anthrop. Oceania, 6:21-33.

Rightmire, G.P., 1972: Cranial measurements and discrete traits compared in distance studies 
of African Negro skulls. Hum. Biol., 44 : 263276.

Rosenberg, B., I. Hershkovitz, E. KoloyLiANSKY and B. Arensburg, 1983: Metric and non-metric variation in three isolated Bedouin populations of the Negev and South Sinai Deserts. J. Hum. Evol., 12 : 337-345.

Rothhammer, F., S. Quevedo, J.A. Cocilovo and E. LLOP, 1984: Microevolution in prehistoric Andean populations: chronologic non- metrical cranial variation in northern Chile. Am. J. Phys. Anthrop., 65 : 157-162.

SoKAL, R. and J.F. RoHLF, 1969: "Biometry. The Principles and Practice of Statistics in Biological Research". W. H. Freeman and Company, San Francisco.

TREVOR, J. C., 1957: Anthropometry. In : “Chambers' Encyclopaedia". (M. D. LAW, ed.), George Newnes Limited, London, Vol. I: 458462.

R. K. PathaK Kothi No. 30, Phase-II

S. A.S. Nagar (Mohali)

Chandigarh-160 051

India 